\title{
SISTEM PENGENDALIAN MANAJEMEN PENGGAJIAN DAN PENGUPAHAN
}

\author{
Irza Triwahyuni, Nevi Costari, M. Muzaki Wildan G \\ Irzatriwahyuni3@gmail.com,nevicstr@gmail.com,muhammadmuzaki9999@gmail.com
}

\begin{abstract}
The purpose of this study was to analyze and find out about the Management Control system in the process of payroll and wages. In addition, the purpose of this study is to determine the effect of an effective and efficient payroll and remuneration management control system, thus facilitating the payroll and remuneration process. The research method used in this study of payroll and remuneration management control systems is to use qualitative descriptive research methods and literature. Management Control System (MSS) is a system designed to collect and display accounting information so that accountants and company executives can make informed decisions. The results of this study indicate that every government agency needs to implement public sector accounting because it can simplify and improve the quality of presenting financial reports.
\end{abstract}

Keywords: : Management control system, Payroll and Wages.

\begin{abstract}
Abstrak
Tujuan dari penelitian ini adalah untuk menganalisis dan mengetahui tentang sistem Pengendalian Manajemen pada proses penggajian dan pengupahan. Selain itu tujuan dari penelitian ini juga, untuk mengetahui pengaruh sistem pengendalian manajemen penggajian dan pengupahan yang efektif dan efisien, sehingga memudahkan dalam proses penggajian dan pengupahan. Metode penelitian yang digunakan dalam penelitian sistem pengendalian manajemen penggajian dan pengupahan ini adalah dengan menggunakan metode penelitian deskriptif kualitatif dan kepustakaan. Sistem Pengendalian Manajemen (SPM) adalah sistem yang dirancang untuk mengumpulkan dan menampilkan informasi akuntansi sehingga akuntan dan eksekutif perusahaan dapat membuat keputusan yang tepat. Hasil dari penelitian ini menunjukkan bahwa setiap instansi pemerintah perlu mengimplementasikan akuntansi sektor publik karena dapat mempermudah dan meningkatkan kualitas dalam menyajikan laporan keuangan.
\end{abstract}

Kata kunci: Sistem pengendalian manajemen, Penggajian dan Pengupahan.

\section{PENDAHULUAN}

Sebagaimana tertera dalam Garis-Garis Besar Haluan Negara (GBHN) bahwa sasaran utama pembangunan jangka panjang adalah terciptanya landasan yang kuat menuju masyarakat adil dan makmur berdasarkan Pancasila dan UUD 1945. Oleh karena itu, pemerintah Indonesia pada masa sekarang ini telah mengupayakan meningkatkan kesejahteraan hidup bagi para tenaga kerja di Indonesia. Pemerintah juga berupaya untuk memberikan himbauan kepada perusahaan-perusahaan 
selaku pemakai jasa tenaga kerja tersebut untuk memberikan imbalan yang layak yang telah diberikan oleh para tenaga kerja tersebut. Perusahaan harus mampu mengendalikan dan membuat tenaga kerja melakukan pekerjaannya agar visi dan misi perusahaan dapat tercapai, sekaligus juga visi dan misi para tenaga kerja tersebut terpenuhi sehingga saling menguntungkan bagi masing-masing pihak. Untuk memperoleh karyawan yang berkualitas, perusahaan memerlukan biaya yang cukup besar, mulai dari proses penerimaan, pendidikan, pelatihan, pembinaan serta meningkatkan kesejahteraan tenaga kerja. Dan salah satu aktivitas penting dalam perusahaan yang berkaitan erat dengan tenaga kerja adalah aktivitas penggajian.

Gaji didefinisikan sebagai pemberian atas prestasi kerja yang telah dicapai dari suatu usaha tenaga kerja. Misalnya gaji harian, gaji mingguan, gaji bulanan dan gaji lainnya. Gaji sebagai tolak ukur suatu prestasi yang dicapai, maka dalam proses penggolongan, penghitungan, penetapan, pencatatan serta pembayarannya memerlukan ketelitian. Gaji tidak hanya mencakup gaji pokok saja, melainkan ada hal-hal yang perlu diperhatikan seperti tunjangan-tunjangan, lembur, dan sebagainya. Seperti halnya Perusahaan Umum Listrik Negara yang bertujuan untuk mencari keuntungan tetapi tidak mengabaikan kepentingan masyarakat. Di lingkungan perusahaan ini yang turut menunjang keberhasilannya adalah di bidang sumber daya manusia atau tenaga kerja yang ada di perusahaan tersebut, karena perusahaan pada umumnya tergantung pada tenaga kerja manusia. Pemberian gaji yang tidak efektif dapat menimbulkan masalah bagi perusahaan terutama berkaitan dengan kinerja SDM. Misalnya, jika karyawan menerima haknya yaitu berupa gaji yang jumlahnya tidak sesuai dengan kewajibannya dalam bekerja, maka dapat mempengaruhi kinerja karyawan tersebut dan kegiatan perusahaan pun akan terhambat. Sehingga untuk menghindari hal tersebut diperlukan pengendalian manajemen penggajian yang menjamin pemenuhan hak tenaga kerja (karyawan). (Yahya et al., 2021) ${ }^{1}$ Suatu sistem pengendalian memiliki beberapa elemen yang memungkinkan pengendalian berjalan baik. Elemen - elemen tersebut adalah (Halim dkk, 2009:5): 1). Sensor atau detektor, yaitu suatu alat untuk mengindentifikasi apa ang sedang terjadi dalam suatu proses; 2). Assesor, yaitu suatu alat untuk menentukan ketepatan. Biasanya ukurannya dengan membandingkan kenyataan dan standar yang telah ditetapkan; 3). Efektor, yaitu alat yang digunakan untuk mengubah sesuatu yang diperoleh dari assesor; 4). Jaringan komunikasi, yaitu alat yang mengirim informasi antara sensor atau detektor dan assesor dan antara assesor dengan efektor. Hariandja (2002) menyatakan bahwa gaji adalah salah satu unsur yang sangat penting yang bisa mempengaruhi kinerja pegawai, sebab gaji dapat dikatakan sebagai alat untuk memenuhi berbagai kebutuhan pegawai itu sendiri, sehingga 
dengan gaji yang diberikan pegawai akan lebih termotivasi untuk bekerja lebih giat, tekun, dan memaksimalkan kemampuan yang dimilikinya secara maksimal.

Tujuan penggajian antara lain : 1). Motivasi. Adanya balas jasa (pembayaran gaji) yang diberikan kepada manajer cukup besar, manajer akan memotivasi karyawannya; 2). Kepuasan kerja. Adanya balas jasa (pembayaran gaji) yang diberikan kepada karyawan, karyawan akan memenuhi kebutuhan - kebutuhan fisik, status sosial, dan egoistik sehingga memperoleh kepuasan kerja dari jabatannya; 3). Disiplin. Adanya balas jasa (pembayaran gaji) yang diberikan kepada karyawan, maka disiplin karyawan semakin baik. Karyawan akan menyadari serta menaati peraturan - peraturan yang berlaku; 4). Stabilitas karyawan. Adanya program kompensasi atau prinsip adil dan layak serta eksternal konsistensi yang kompentatif, maka stabilitas karyawan lebih terjamin; 5). Ikatan kerjasama. Adanya pemberian gaji terjalinlah ikatan kerjasama formal antar atasan dengan karyawan. Karyawan harus mengerjakan tugas - tugas dengan baik, sedangkan atasan wajib membaar gaji yang sesuai dengan perjanjian yang telah disepakati. (Sinain, 2013)²

\section{KAJIAN TEORI}

\section{A. Sistem Pengendalian Manajemen}

Pengertian Sistem Pengendalian Manajemen

Sistem Pengendalian Manajemen dapat dikatakan sehagai pengetahuan teoritispraktis dan dapat pula dikategorikan sebagai bagian dari pengetahuan perilaku terapan. Dikatakan pengetahuan teoritis-praktis, karena akan lebih mudah mencerna kalau dalam mempelajarinya senantiasa membayangkan dan mengaitkannya dengan perilaku manusia dalam kehidupan organisasi/perusahaan. Dikatagorikan sebagai bagian dari pengetahuan perilaku terapan, karena pada dasarnya sistem ini berisi tuntunan mengenai cara mengendalikan perusahaan dengan baik berdasarkan asumsi-asumsi tertentu.

Sistem pengendalian manajemen menurut Robert J. Mackler merupakan segala upaya sistematis oleh manajemen bisnis untuk membandingkan kinerja dengan standar yang telah ditentukan, rencana, atau tujuan untuk menentukan apakah kinerja sejalan dengan standar tersebut dan mungkin untuk mengambil tindakan perbaikan yang diperlukan untuk melihat bahwa manusia dan sumber daya perusahaan lainnya yang digunakan dengan cara yang paling efektif dan efisien mungkin dalam mencapai tujuan perusahaan.

Selain itu, Sistem pengendalian manajemen merupakan bagian dari akuntansi manajemen dimana akuntansi manajemen berhubungan dengan penyediaan informasi 
keuangan dan non keuangan bagi para manajer untuk memastikan efisien dan efektivitas kinerja sebuah organisasi. Yang selanjutnya akuntansi manajemen akan mengidentifikasi, mengukur, menganalisis dan mengumpulkan informasi akuntansi untuk para manajer yang akan digunakan untuk merencanakan, mengevaluasi dan mengendalikan sumber daya perusahaan untuk mencapai tujuan perusahaan. Sehingga bisa dikatakan bahwa akuntansi manajemen merupakan sistem pendukung keputusan yang melayani manajemen di semua tingkatan dan dapat dianggap sebagai proses perbaikan berkelanjutan yang menambah nilai bagi perusahaan. (Eko, 2018) ${ }^{3}$

Secara umum, dapat dikatakan bahwa akuntansi manajemen memungkinkan organisasi menerima informasi tepat tentang perubahan di masing - masing departemen dan efeknya pada departemen lain dan organisasi secara keseluruhan. Akuntansi manajemen akan mendeteksi masalah pada tahap awal, memungkinkan manajemen untuk membuat keputusan bisnis yang lebih baik, meningkatkan keseluruhan kinerja serta kemajuan proses perencanaan dan Kompartemen. Oleh karena itu akuntansi manajemen memberikan informasi bernilai tinggi tentang perusahaan untuk memudahkan pengambilan keputusan bagi para manajer

Tujuan Sistem Pengendalian Manajemen

Tujuan utama sistem pengendalian manajemen merupakan untuk menyelaraskan tujuan - tujuan itu, yaitu maka sistem harus dirancang sedemikian rupa sehingga tindakantindakan setiap anggota perusahaan untuk meraih kepentingannya sendiri bisa selaras dengan kepentingan perusahaan. Sejalan dengan pendapat yang dikemukan bahwa kinerja merupakan penampilan hasil karya pada seluruh jajaran personil di dalam suatu organisasi. Selain itu, tujuan pengendalian manajemen dapat memotivasi manajer-manajer untuk memunculkan suatu tingkat usaha yang tinggi untuk mencapai tujuan-tujuan manajemen puncak, memberikan insentif yang tepat pada manajer-manajer untuk membuat keputusankeputusan yang konsisten dengan tujuan manajemen puncak, dan secara adil menentukan penghargaan yang diperoleh oleh manajer atas usaha dan keterampilan mereka, atas keefektifan pembuatan keputusan mereka.

\section{Karakteristik Sistem Pengendalian Manajemen}

Terdapat enam karakteristik pengendalian manajemen antara lain yaitu sebagai berikut : 
1) Dipusatkan pada program-program dan pusat pertanggungjawaban.

2) Informasi yang diproses dari dua jenis data terencana berbentuk program, anggaran ataustandar dan data aktual di dalam maupun luar organisasi.

3) Merupakan sistem yang menyeluruh, yang merangkum semua aspek dalam organisasi.

4) Berhubungan dengan struktur keuangan.

5) Aspek perencanaannya mengikuti pola dan jadwal tertentu, dalam hal ini penyusunan anggaran merupakan kegiatan penting dalam proses pengendalian.

6) Merupakan sistem yang terkoordinasi dan terpadu, data dikumpulkan, digabungkan dan diperbandingkan setiap saat pada setiap unit organisasi.

Ciri - Ciri Penting Sistem Pengendalian Manajemen

1) Sistem pengendalian manajemen digunakan untuk mengendalikan seluruh organisasi, termasuk pengendalian terhadap seluruh sumber daya (resources) yang digunakan, baik manusia, alat-alat dan teknologi, maupun hasil yang diperoleh organisasi, sehingga proses pencapaian tujuan organisasi dapat berjalan lancar.

2) Pengendalian manajemen bertolak dari strategi dan teknik evaluasi yang berintegrasi dan menyeluruh, serta kurang bersifat perhitungan yang pasti dalam mengevaluasi sesuatu.

3) Pengendalian manajemen lebih berorientasi pada manusia, karena pengendalian manajemen lebih ditujukan untuk membantu manajer mencapai strategi organisasi dan bukan untuk memperbaiki detail catatan

\section{Unsur-Unsur Sistem Pengendalian Manajemen}

Menurut (Sumarsan, 2011:9) Suatu sistem pengendalian manajemen yang dapat diandalkan harus memenuhi unsur-unsur berikut :

1) Keahlian karyawan (pegawai) sesuai dengan tanggung jawabnya.

2) Pemisahan tugas.

3) Sistem pemberian wewenang, tujuan dan teknik serta pengawasan yang wajar untuk mengadakan pengendalian atas harta, utang, penerimaan, dan pengeluaran.

4) Pengendalian terhadap penggunaan harta dan dokumen serta formulir yang penting.

5) Periksa fisik harta dengan catatan-catatan harta dan utang, atau yang benar-benar ada, dan mengadakan tindakan koreksi jika dijumpai adanya perbedaan. 


\section{Elemen - Elemen Penting Sistem Pengendalian Manajemen}

Suatu sistem pengendalian memiliki beberapa elemen yang memungkinkan pengendalian berjalan baik. Elemen-elemen tersebut sebagai berikut :

1) Sensor/Detektor, yakni suatu alat untuk mengidentifikasi apa yang sedang terjadi dalam suatu proses.

2) Assesor, yakni suatu alat untuk menentukan ketepatan. Biasanya ukurannya dengan membandingkan kenyataan dan standar yang telah ditetapkan.

3) Efektor, yakni alat yang digunakan untuk mengubah sesuatu yang diperoleh dari assessor.

4) Jaringan Komunikasi, yakni alat yang mengirim informasi antara detektor dan assesor dan antara assesor dan efektor. (Halim dkk,2009:5)

\section{Struktur Sistem Pengendalian Manajemen}

Struktur merupakan bagian dari sistem pengendalian manajemen, yang berpusat pada bermacam-macam jenis pusat pertanggungjawaban. Pusat pertanggungjawaban merupakan unit organisasi yang dipimpin oleh seorang manajer yang bertanggung jawab. Setiap pusat pertanggungjawaban mempunyai masukan dan keluaran. Pada dasarnya terdapat empat jenis pusat pertanggungjawaban menurut Sumarsan (2013), yaitu sebagai berikut :

\section{1) Pusat Biaya (cost center) \\ 2) Pusat Pendapatan (revenue center) \\ 3) Pusat Laba (profit center) \\ 4) Pusat Investasi (investement center)}

\section{Manfaat Sistem Pengendalian Manajemen}

Sistem pengendalian juga memiliki berbagai manfaat bagi sebuah perusahaan, sebagai berikut yaitu : dapat mengetahui sudah sejauh mana program yang sedang dilakukan oleh perusahaan. Sistem pengendalian manajemen juga dapat melihat apakah sudah sesuai dengan standar serta rencana kerja yang telah ditetapkan, dapat mengetahui jika ada berbagai penyimpangan yang terjadi dalam proses pengerjaan suatu aktivitas, dapat mengetahui bagaimana waktu serta sumber daya yang disediakan dapat tercukupi serta dimanfaatkan oleh perusahaan dengan baik, dapat mengetahui berbagai faktor yang menjadi penyebab terjadinya penyimpangan suatu aktivitas, dapat memberikan ruang bagi supervisi 
perusahaan untuk melihat serta merenungkan pekerjaan yang mereka miliki, dapat menerima informasi serta berbagai perspektif dari orang lain mengenai sebuah aktivitas, dapat mendukung setiap anggota perusahaan baik dari segi personal maupun pekerjaan yang sedang dilakukan, memastikan setiap orang memberikan reaksi yang proaktif serta reaktif, memastikan kualitas setiap pekerjaan yang dilakukan memenuhi standar yang telah ditentukan, dan untuk memastikan setiap anggota perusahaan tidak mengalami kesulitan ataupun masalah baik dalam hal pribadi maupun tugas perusahaan.

Proses Sistem Pengendalian Manajemen

Langkah-langkah proses sistem pengendalian manajemen adalah sebagai berikut :

1) Perencanaan Strategis (penyusunan program)

2) Penyusunan Anggaran (penganggaran)

3) Pelaksanaan dan pengukuran

4) Analisis dan pelaporan prestasi

\section{B. Sistem Penggajian (Gaji) dan Pengupahan (Upah)}

Pengertian Sistem Penggajian dan Pengupahan

Sistem penggajian dan pengupahan dalam suatu perusahaan sangat dibutuhkan, karena dengan adanya sistem penggajian dan pengupahan ini dapat mengorganisir proses penerimaan atau pemberian gaji dan upah pada setiap orang yang bekerja di dalam suatu perusahaan, sehingga dapat memberikan efisiensi dan efektivitas dalam proses penggajian dan pengupahan tersebut.

Sistem akuntansi penggajian menurut (Mulyadi, 2016:373) merupakan sebuah fungsi, dokumen, catatan, dan sistem pengendalian intern yang digunakan untuk kepentingan harga pokok produk dan penyediaan informasi guna pengawasan biaya tenaga kerja. Sistem akuntansi penggajian dan pengupahan ini dirancang untuk menangani transaksi perhitungan gaji dan upah karyawan dan pembayarannya. Sistem ini terdiri dari jaringan prosedur yaitu: Prosedur pencatatan waktu hadir, Prosedur pembuatan daftar gaji, Prosedur distribusi biaya gaji, Prosedur pembuatan bukti kas keluar, dan prosedur pembayaran gaji (Mulyadi, 2016:385).

Pengertian penggajian (gaji) merupakan suatu sistem yang mengatur tata cara pemberian gaji/upah kepada segenap karyawan dalam organisasi. Di samping itu, gaji dan upah dikenal pula dengan istilah penghasilan bersih, atau juga disebut dengan imbal jasa. 
Sedangkan pengertian pengupahan (upah) merupakan hak yang dimiliki oleh pekerja atau karyawan yang diterima dan dinyatakan dalam bentuk uang sebagai bentuk imbalan dari pengusaha atau pemberi kerja kepada pekerja yang ditetapkan dan dibayarkan menurut suatu perjanjian kerja, kesepakatan atau peraturan perundang-undangan, termasuk juga tunjangan bagi pekerja dan keluarganya atas suatu pekerjaan dan atau jasa yang telah atau akan dilakukan tersebut. Selain itu pengertian sistem akuntansi penggajian dan pengupahan meruapakan sebuah sistem akuntansi penggajian dan pengupahan dalam perusahaan jasa kontruksi melibatkan fungsi karyawan, keuangan dan fungsi akuntansi. (Prianthara 2013:137)

Dalam proses penggajian dan pengupahan membutuhkan banyak dokumendokumen atau prosedur-prosedur dalam pelaksanaannya, oleh karena itu sangat diperlukan dibuatnya Sistem Informasi Akuntansi Penggajian dan Pengupahan di setiap perusahaan atau organisasi yang efektif dan efisien baik juga dalam proses pelaksanaannya. Dapat disimpulkan bahwa Sistem Informasi Akuntansi Penggajian dan Pengupahan merupakan suatu sistem yang dirancang untuk membuat informasi-informasi tentang penggajian dan pengupahan, dimana disusun dan dilaksanakan secara sistematis sesuai dengan sistem akuntansi yang baik dan benar.

Fungsi-Fungsi Yang Terkait Sistem Akuntasi Penggajian Dan Pengupahan

Fungsi-fungsi umum yang terkait dengan sistem akuntansi penggajian dan pengupahan sangat diperlukan ketepatan dalam pemilihan fungsi yang nantinya akan digunakan tersebut, jangan sampai ada fungsi yang telah dipilih namun dalam penggunaan fungsi tersebut kurang efektif dan efisien, sehingga fungsi tersebut nantinya akan mengganggu dalam sebuah penerapannya. Namun, fungsi tersebut bisa digantikan dengan fungsi yang lainnya. Menurut (Mulyadi, 2016:317) fungsi yang biasanya di gunakan dalam suatu perusahaan adalah sebagai berikut, yaitu :

1) Fungsi Kepegawaian : Fungsi ini bertanggungjawab untuk mencari karyawan baru, menyeleksi calon karyawan, memutuskan penempatan posisi karyawan, membuat surat keputusan tarif gaji dan upah karyawan, kenaikan pangkat dan golongan gaji, mutasi karyawan, dan pemberhentian karyawan.

2) Fungsi Pencatat Waktu : Fungsi ini bertanggungjawab untuk menyelenggarakan catatan waktu hadir bagi semua karyawan perusahaan. Sistem pengendalian internal yang baik mensyaratkan fungsi pencatatan waktu hadir karyawan tidak boleh dilaksanakan oleh 
fungsi operasi atau oleh fungsi pembuat daftar gaji dan upah atau bisa disebut dengan fungsi ganda.

3) Fungsi Pembuat Daftar Gaji dan Upah : Fungsi ini bertanggungjawab untuk membuat daftar gaji dan upah yang berisi penghasilan bruto yang menjadi hak dan berbagai potongan yang menjadi beban setiap karyawan selama jangka waktu pembayaran gaji dan upah. Daftar gaji dan upah diserahkan oleh fungsi pembuat daftar gaji dan upah kepada fungsi akuntansi untuk pembuatan bukti kas keluar yang nantinya dipakai sebagai dasar untuk pembayaran gaji dan upah kepada karyawan.

4) Fungsi Akuntansi Dalam sistem akuntansi penggajian dan pengupahan : fungsi atau bagian akuntansi ini bertanggungjawab penuh untuk mencatat kewajiban yang timbul dalam hubungannya dengan pembayaran gaji dan upah karyawan (misalnya utang gaji dan upah karyawan, utang pajak, dan ataupun utang dana pensiun). Fungsi akuntansi yang menangani sistem akuntansi penggajian dan pengupahan meliputi yaitu :

a) Bagian Utang : Bagian ini berfungsi untuk memegang pencatatan utang yang dalam sistem akuntansi penggajian dan pengupahan bertanggung jawab untuk memproses pembayaran gaji dan upah. Bagian ini menerbitkan bukti kas keluar yang memberi otorisasi kepada fungsi pembayar gaji dan upah untuk membayarkan gaji dan upah kepada karyawan.

b) Bagian Kartu Biaya : Bagian ini memegang fungsi akuntansi biaya yang dalam sistem akuntansi penggajian dan pengupahan bertanggung jawab untuk mencatat distribusi biaya ke dalam kartu harga pokok produk dan kartu biaya berdasarkan rekap daftar gaji dan upah dan kartu jam kerja (untuk tenaga kerja langsung pabrik).

c) Bagian Jurnal Bagian ini memegang fungsi pencatat jurnal yang bertanggung jawab untuk mencatat biaya gaji dan upah dalam jurnal umum.

5) Fungsi Keuangan Fungsi ini bertanggungjawab untuk mengisi cek guna pembayaran gaji dan upah dan menguangkan cek tersebut ke bank. Utang tunai tersebut kemudian dimasukkan ke dalam amplop gaji dan upah setiap karyawan, untuk selanjutnya dibagikan kepada karyawan yang berhak.

\section{Dokumen Yang Digunakan Dalam Sistem Penggajian Dan Pengupahan}

Dokumen dalam sistem penggajian dan pengupahan sebaiknya lengkap dan transparan, agar tidak terjadi kecurangan-kecurangan yang tidak diinginkan. dokumen yang digunakan dalam sistem penggajian dan pengupahan adalah: 
1) Dokumen Pendukung Perubahan Gaji dan Upah Dokumen ini umumnya dikeluarkan oleh fungsi kepegawaian berupa surat keputusan yang bersangkutan dengan karyawan.

2) Kartu Jam Hadir Dokumen digunakan oleh fungsi pencatat waktu untuk mencatat jam hadir setiap karyawan di perusahaan. Catatan jam hadir ini dapat berupa daftar hadir biasa atau berbentuk kartu hadir yang diisi dengan mesin pencatat waktu.

3) Kartu Jam Kerja Dokumen ini digunakan untuk mencatat waktu yang dikonsumsi oleh tenaga kerja langsung pabrik guna mengerjakan pesanan tertentu. Dokumen ini diisi oleh mandor dan diserahkan ke fungsi pembuat daftar gaji dan upah untuk distribusi biaya upah langsung kepada setiap jenis produk.

4) Daftar Gaji dan Daftar Upah Dokumen ini berisi jumlah gaji dan upah bruto setiap karyawan, dikurangi potongan-potongan berupa $\mathrm{PPh}$ pasal 21, utang karyawan, iuran untuk organisasi karyawan, dan lain sebagainya.

5) Rekap Daftar Gaji dan Rekap Daftar Upah Dokumen ini merupakan ringkasan gaji dan upah per departemen yang dibuat berdasarkan daftar gaji dan upah. Dalam perusahaan yang produksinya berdasarkan pada pesanan, rekap gaji dan upah dibuat untuk membebankan upah langsung dalam hubungannya dengan produk kepada pesanan yang bersangkutan. Distribusi biaya tenaga kerja ini dilakukan oleh fungsi akuntansi biaya dengan rekap daftar gaji dan upah.

6) Surat Pernyataan Gaji dan Upah Dokumen ini dibuat oleh fungsi pembuat daftar gaji dan upah bersamaan dengan pembuatan daftar gaji dan upah atau dalam kegiatan yang terpisah dari pembuatan daftar gaji dan upah. Dokumen ini dibuat sebagai catatan bagi setiap karyawan mengenai rincian gaji dan upah yang diterima setiap karyawan besert berbagai potongan yang menjadi beban setiap karyawan.

7) Amplop Gaji dan Upah Uang gaji dan upah karyawan diserahkan setiap karyawan dalam amplop gaji dan upah. Di halaman depan amplop gaji dan upah setiap karyawan ini berisi informasi mengenai nama karyawan, nomor identifikasi karyawan dan jumlah gaji bersih yang diterima karyawan dalam periode tertentu.

8) Bukti Kas Keluar Dokumen ini merupakan perintah pengeluaran uang yang dibuat oleh fungsi/departemen keuangan berdasarkan informasi dalam daftar gaji dan upah yang diterima dari fungsi pembuat daftar gaji dan upah.

Keseluruhan dokumen-dokumen tersebut harus disiapkan agar proses sistem informasi penggajian dan pengupahan dilaksanakan secara efektif dan efisien tanpa adanya kesalahan ataupun kekurangan sedikitpun. 


\section{Catatan Akuntansi Yang Digunakan Dalam Sistem Penggajian dan Pengupahan}

Catatan-catatan akuntansi yang digunakan dalam sistem penggajian dan pengupahan harus dibuat dengan baik dan tersimpan dengan aman, karena catatan-catatan tersebut merupakan bukti yang nyata atas setiap transaksi yang berhubungan dengan penggajian dan pengupahan dalam perusahaan tersebut, dan juga dapat menghindarkan perusahaan dari kerugian atau kecurangan-kecurangan yang bisa saja terjadi. Mulyadi (2016:382) menyatakan bahwa catatan akuntansi yang digunakan dalam sistem penggajian dan pengupahan meliputi:

1) Jurnal Umum : Jurnal umum digunakan untuk mencatat distribusi biaya tenaga kerja dalam tiap departemen di perusahaan.

2) Kartu Harga Pokok Produk : Catatan ini digunakan untuk mencatat upah tenaga kerja langsung yang dikeluarkan untuk pesanan tertentu.

3) Kartu Biaya : Catatan ini dipergunakan untuk mencatat biaya tenaga kerja tidak langsung dan biaya tenaga kerja nonproduksi setiap departemen dalam perusahaan. Sumber informasi untuk pencatatan dalam kartu biaya ini adalah bukti memorial.

4) Kartu Penghasilan Karyawan : Catatan mengenai penghasilan dan berbagai potongan yang diterima oleh setiap karyawan. Informasi dalam kartu penghasilan karyawan ini dipakai sebagai dasar perhitungan PPh pasal 21. Kartu penghasilan karyawan digunakan juga untuk tanda terima gaji dan upah karyawan dengan ditandatangani kartu tersebut oleh karyawan yang bersangkutan.

\section{METODE PENELITIAN}

Model metode penelitian yang dipakai adalah deskriptif analisis dengan pendekatan kualitatif yang bertujuan mendeskripsikan dan menggambarkan informasi yang ada. Metode deskriptif yaitu merupakan penelitian dengan data kualitatif yang kemudian diolah dan dianalisis untuk diambil kesimpulan. Sumber dan jenis data yang digunakan dalam penelitian ini adalah data sekunder. Data sekunder merupakan sumber data penelitian, yang diperoleh melalui media perantara atau orang lain, atau secara tidak langsung yang berupa buku, catatan, bukti yang telah ada, atau arsip yang telah dipublikasikan maupun yang tidak dipublikasikan secara umum. Metode analisis yang digunakan adalah metode analisis interaktif, dengan analisa model 
interaktif yang dikembangkan oleh Milles dan Hubberman (dalam Moleong :307), yang terdiri dari 3 komponen analisis yaitu:

1) Reduksi data, yaitu proses pemilihan, pemberian fokus, penyederhanaan dan transformasi data mentah terdapat di lapangan. Hal ini bertujuan untuk mempertajam, menggolongkan, menyortir dan mengorganisasikan data.

2) Penyajian data, yaitu proses penyusunan informasi yang kompleks ke dalam bentuk yang sistematis dan memberi kemungkinan adanya penarikan kesimpulan dan pengambilan keputusan. Bentuk paling umum yang digunakan berupa teks uraian.

3) Penarikan kesimpulan/verifikasi, merupakan akhir kegiatan analisis berupa penarikan kesimpulan dengan cara meninjau ulang data-data yang diperoleh dilapangan agar data tersebut valid.

Sifat-sifat evaluasi menurut William N. Dunn (2003 : 608) sebagai berikut:

1) Fokus Nilai. Evaluasi berbeda dengan pemantauan, dipusatkan pada penilaian menyangkut keperluan atau nilai dari suatu kebijakan dan program.

2) Interdependensi Fakta Nilai.

3) Orientasi Masa Kini dan Masa Lampau.

4) Kualitas Nilai.

Sedangkan metode deskriptif menurut Sugiyono adalah: "Metode yang digunakan untuk menggambarkan atau menganalisis suatu hasil penelitian tetapi tidak digunakan untuk membuat kesimpulan yang lebih luas". Selain itu, Sugiono juga mengemukakan bahwa pendekatan kualitatif sebagai metode penelitian yang berlandaskan pada filsafat postpositivisme, digunakan untuk meneliti pada kondisi objek alamiah, dimana peneliti adalah sebagai instrumen kunci, teknik pengumpulan data dengan triangulasi, analisis dat bersifat induktif atau kualitatif, daan hasil penelitian kualitatif lebih menekankan makna daripada generalisasi. Penelitian ini menafsirkan dan menguraikan data yang bersangkutan dengan situai yang sedang terjadi kemudian membandingkannya dengan peraturan yang sudah ditetapkan. baru sebanyak satu inci dengan format teks rata kiri kanan. (Pabowo \& Eldon, 2018) ${ }^{4}$

\section{HASIL PENELITIAN DAN PEMBAHASAN}

Analisis Sistem Pengendalian Manajemen Penggajian Pada perusahaan 
1) Dokumen - dokumen yang digunakan :

-Daftar hadir karyawan, untuk mencatat kehadiran karyawan setiap hari pada saat datang sebelum memulai kerja dan pulang kerja dengan melakukan absensi manual yang diawasi oleh bagian pencatatan kehadiran.

- Rekap daftar hadir karyawan untuk mencatat rekap jam hadir karyawan tetap yang dihitung selama satu bulan.

- Daftar gaji karyawan untuk mencatat jumlah gaji pokok dari masing - masing karyawan, ditambah tunjangan

- tunjangan dan dikurangi potongan-potongan.

- Slip gaji, slip gaji dibuat oleh bagian akuntansi yang berisi rincian gaji yang diterima oleh karyawan

Dokumen dokumen untuk penggajian pada perusahaan harus sesuai dengan teori yang ada. Dokumen yang digunakan harus memadai dan mendukung system pengendalian manajemen penggajian. Juga dapat memanfaatkan sebagian fungsi seperti system fingerprint, gaji karyawan tanpa transfer rekening, serta rekap harian yang masih manual.

\section{Analisis Efektifitas Unsur - Unsur Sistem Pengendalian Manajemen Pada perusahaan}

\begin{tabular}{|l|l|}
\hline Unsur-Unsur Sistem Pengendalian Manajemen & Hal-Hal Yang Mendukung \\
\hline $\begin{array}{l}\text { Keahlian karyawan (pegawai) sesuai dengan } \\
\text { tanggung jawabnya. }\end{array}$ & $\begin{array}{l}\text { Hal ini dapat terlihat dengan adanya pelatihan } \\
\text { terlebih dahulu sebelum pegawai diterima } \\
\text { bekerja }\end{array}$ \\
\hline $\begin{array}{l}\text { Pemisahan tugas. } \\
\begin{array}{l}\text { Sistem pemberian wewenang, tujuan dan } \\
\text { teknik serta pengawasan yang wajar untuk } \\
\text { mengadakan pengendalian atas harta, utang, } \\
\text { penerimaan, dan pengeluaran. }\end{array}\end{array}$ & $\begin{array}{l}\text { Sudah terdapat pemisahan tugas yang cukup } \\
\text { jelas dan dapat dilihat dari struktur organisasi } \\
\text { yang ada }\end{array}$ \\
\end{tabular}




\begin{tabular}{|l|l|}
\hline $\begin{array}{l}\text { Pengendalian terhadap penggunaan harta dan } \\
\text { dokumen serta formulir yang penting. }\end{array}$ & $\begin{array}{l}\text { Hal ini dapat dilihat dari dokumen - dokumen } \\
\text { yang dibuat dan dikeluarkan selalu diotorisasi } \\
\text { kebenarannya. Selain itu, dokumendokumen } \\
\text { disimpan dengan baik dan rapi sehingga } \\
\text { memudahkan untuk mencari pada saat } \\
\text { diperlukan. }\end{array}$ \\
\hline $\begin{array}{l}\text { Periksa fisik harta dengan catatan - catatan } \\
\text { harta dan utang, dan mengadakan tindakan } \\
\text { koreksi jika dijumpai adanya perbedaan. }\end{array}$ & $\begin{array}{l}\text { Segala catatan-catatan yang ada selalu } \\
\text { diperiksa setiap harinya, dan langsung } \\
\text { dikoreksi saat itu juga jika terjadi kesalahan } \\
\text { pada catatan tersebut }\end{array}$ \\
\hline
\end{tabular}

\section{Analisis Prosedur Dalam Sistem Penggajian Pada perusahaan}

\section{Prosedur Pencatatan Daftar Hadir}

Karyawan Prosedur ini diwajibkan semua karyawan melakukan absensi dengan menggunakan absensi secara manual dengan menggunakan buku absen yang dipegang oleh personalia. Berikut kegiatan uraiannya :

- Setiap karyawan melakukan absensi manual pada waktu masuk dan pulang kerja dan di awasi oleh bagian pencatatan kehadiran.

- Membuat rekapan daftar hadir karyawan berdasarkan catatan waktu hadir karyawan

\section{Prosedur Pembuatan Daftar Gaji Prosedur}

ini adalah untuk membuat daftar gaji dalam rangka pembayaran gaji. Dalam daftar gaji dicantumkan penghasilan karyawan yang terdiri dari gaji pokok, lembur, juga mencantumkan jumlah pinjaman yang dilakukan oleh karyawan beserta dengan potonganpotongan yang ada. Dalam perusahaan ini, prosedur pembuatan daftar gaji dan pencatatan gaji ditangani oleh bagian administrasi

\section{Prosedur Pembayaran Gaji Prosedur}

Ini dilakukan secara manual oleh pihak PT. Dimana setiap daftar gaji yang telah berhasil di buat/direkap oleh bagian admin harus diperiksa terlebih dahulu oleh manager dan setelah selesai langsung dibawa pada pemilik PT untuk disetujui. Kemudian daftar gaji dibawa di bagian keuangan dan kemudian menyiapkan uang tunai untuk membayar setiap hak karyawan yaitu gaji sesuai dengan daftar gaji yang telah diterimanya. Prosedur ini dilakukan oleh bagian keuangan dengan uraian kegiatan sebagai berikut: - Menerima hasil rekap 
struktur gaji karyawan dari bagian administrasi - Melakukan pemeriksaan terhadap rekap gaji yang ada - Meminta persetujuan kepada pemilik PT untuk dilakukan pengeluaran sejumlah kas untuk pembayaran gaji karyawan - Mendapat persetujuan pemilik PT mengeluarkan kas untuk membayar gaji karyawan. - Memberikan gaji berbentuk uang tunai rupiah beserta slip gaji yang dimasukkan kedalam amplop yang telah disediakan dan senjutnnya diberikan kepada masing-masing karyawan.

\section{Analisis Fungsi - Fungsi yang Terkait dalam Sistem Pengendalian Manajemen Penggajian Pada Perusahaan}

Fungsi - fungsi yang terkait dalam sistem pengendalian manajemen penggajian pada Perusahaan adalah:

a. Direktur

Direktur berwenang dalam proses pembayaran gaji pokok karyawan. Melakukan transfer gaji pokok, tunjangan transport, uang makan, dan premi hadir ke masing - masing karyawan dan menbayar biaya pembayaran pendapatan per bulan ke Bagian Akuntansi.

b. Bagian Akuntansi

Bagian akuntansi bertugas untuk membuat rekap daftar hadir karyawan, daftar gaji karyawan, slip gaji, lembar penerimaan gaji, bukti kas keluar, dan bertanggung jawab mencatat transaksi - transaksi penggajian pada jurnal umum dan buku besar.

Fungsi-fungsi yang terkait dengan sistem informasi akuntansi penggajian pada sistem pengendalian manajemen penggajian pada PT. Aura Mandiri kurang baik. Alternatif alternatif untuk mengurangi kelemahan pada fungsi - fungsi yang terkait dalam sistem informasi akuntansi penggajian yaitu antara lain :

- Terdapat bagian khusus seperti fungsi pembuat daftar gaji (bagian akuntansi) yang bertanggung jawab untuk membuat daftar gaji yang berisi gaji pokok serta tunjangantunjangan yang diberikan kepada karyawan dan potongan - potongan yang menjadi beban karyawan setiap bulannya.

- Daftar gaji tersebut dikelola oleh fungsi pembuat daftar gaji guna pembuatan daftar gaji yang akan diajukan ke kasir, untuk pembayaran gaji pegawai.

- Fungsi pencatat waktu (bagian personalia) yang bertanggungjawab untuk membuat rekap daftar hadir karyawan dan menyelenggarakan waktu hadir bagi semua karyawan PT. Aura Mandiri. Sistem pengendalian intern yang baik mensyaratkan fungsi pencatatan waktu hadir 
karyawan tidak boleh dilaksanakan oleh fungsi operasi atau oleh fungsi pembuat daftar gaji dan upah.

\section{Catatan manajemen penggajian dan pengupahan yang efektif}

Panduan dasar tentang perencanaan, penyusunan, dan pengelolaan penggajian untuk para karyawan. Tiap jenis perusahaan menerapkan sistem penggajian dan pengupahan yang berbeda. Pada kesempatan ini jenis perusahaan yang akan dijadikan contoh penerapan manajemen penggajian dan pengupahan karyawan. Dalam sistem manajemen penggajian dan pengupahan di perusahaan manufaktur, terdapat beberapa pihak yang terlibat, yaitu bagian keuangan, bagian akuntansi, dan bagian personalia.

- Bagian Personalia

Bagian persoanlia dalam sistem manajemen penggajian dan pengupahan memiliki peran merekrut karyawan baru sesuai dengan kebutuhan perusahaan, menetapkan jabatan, menetapkan besarnya gaji dan upah, dan pemberian promosi serta penurunan jabatan, menentukan mutasi karyawan, pemecatan karyawan, dan menetapkan besaran tunjangan serta menghitung besaran gaji karyawan.

- Bagian Keuangan

Berbeda dengan bagian persoanlia, bagian keuangan memiiiki tugas untuk melakukan pembayaran gaji dan tunjangan karyawan dalammanajemen penggajian.

- Bagian Akuntansi

Bagian akuntansi bertanggung jawab dalam mencatat semua biaya tenaga kerja serta mendistribusikan biaya tenaga kerja guna mengetahui keseimbangan keuangan perusahaan. Adapun data-data yang diperlukan oleh pihak manajemen dalam merancang dan menyusun penggajian karyawan, yaitu:

- Besaran gaji dan upah yang termasuk beban perusahaan dalam periode tertentu.

- Rincian komponen biaya gaji dan upah yang masuk dalam daftar beban perusahaan dalam periode tertentu

- Besarnya biaya gaji dan upah yang menjadi beban tiap produk dan tiap fungsi pertanggungjawaban dalam periode tertentu.

- Besaran gaji dan upah yang diterima oleh tiap karyawan dalam periode tertentu.

Bagian akuntansi tentunya juga menggunakan beberapa catatan akuntansi dalam merancang dan menyusun penggajian dan upah. Catatan-catatan akuntansi tersebut antara lain: 
- Kartu harga pokok

- Kartu biaya

- Jurnal umum

- Kartu penghasilan milik tiap karyawan

Beberapa jenis unit organisasi yang ikut terlibat dalam penyusunan gaji dan upah karyawan antara lain:

- Bagian Utang

- Bagian Kepegawaian

- Bagian Gaji dan Upah

- Bagian Pencatat Waktu

Sistem Informasi Akuntansi (SIA) yang terkait dengan manajemen penggajian dan pengupahan karyawan memiliki peranan yang sangat penting sebagai acuan untuk penyusunan laporan manajemen penggajian periode berikutnya. Laporan ini juga bermanfaat untuk menjadi pertimbangan dalam menyusun dan mengaplikasikan SIA yang sebelumnya sudah pernah diterapkan oleh perusahaan.

\section{Jaringan prosedur yang membentuk system untuk mendukung pengendalian manajemen penggajian dan pengupahan. Hal ini dapat dilihat dari :}

a) Prosedur penerimaan pegawai

berikut adalah langkah-langkah yang dapat digunakan untuk memandu proses rekrutmen yang ideal:

1. Menganalisis kebutuhan posisi dan posisi

Perusahaan harus menentukan terlebih dahulu kebutuhan rekrutmen karyawan baru. Jika karyawan lama tidak dapat segera mendapatkan bantuan, beban kerja yang meningkat akan menurunkan kinerja. Alasan lain yang mungkin untuk kebutuhan rekrutmen adalah pembukaan departemen baru atau transfer posisi.

2. Merencanakan proses rekrutmen

Proses rekrutmen selanjutnya adalah perusahaan menyiapkan rencana untuk posisi yang dibutuhkan. Tuliskan deskripsi pekerjaan, kualifikasi dan pengalaman yang dibutuhkan. Dan menentukan di mana menempatkan iklan pekerjaan di media cetak atau online. Selain itu, jangan lupa untuk mengidentifikasi penanggung jawab pekerjaan dari tim pengembangan sumber daya manusia, memantau proses, mengklasifikasikan pelamar, melakukan wawancara, dan terakhir memberikan kesempatan kerja. 


\section{Pasang lowongan}

Tim pengembangan sumber daya manusia dapat mempublikasikan pengumuman internal tentang lowongan kerja baru untuk mendapatkan lowongan kerja dari sumber daya manusia yang ada. Kemudian memilih media yang menerbitkan iklan lowongan kerja, seperti media cetak atau online yang memiliki pangsa pasar pembaca yang sesuai dengan kebutuhan perusahaan. Selain itu, tim HRD juga dapat menggunakan layanan portal khusus pencari kerja online, seperti Jobstreet, IndoJobs, Karir.com, dll. Halaman LinkedIn perusahaan juga dapat digunakan untuk menarik pelamar yang memenuhi syarat. Tim SDM juga dapat mencari melalui filter atau menempatkan iklan di LinkedIn untuk menemukan kandidat berkualitas lebih tinggi.

4. Memproses lamaran kerja dan melakukan wawancara

Dengan iklan pekerjaan yang efektif, lamaran pekerjaan akan segera tiba. Sebelumnya, pastikan tim pengembangan SDM sudah menyiapkan kriteria seleksi untuk membantu proses eliminasi jika pelamar terlalu banyak. Untuk menyederhanakan proses, Anda dapat menghubungi pelamar yang memenuhi syarat dan memenuhi syarat melalui telepon atau pesan teks untuk memberitahu mereka tentang jadwal wawancara yang dijadwalkan.

5. Pilih kandidat yang cocok dan berikan kesempatan kerja

Jika semua langkah di atas sudah selesai, maka tim HRD akan siap untuk menyeleksi kandidat yang sesuai dengan kebutuhan perusahaan. Kemudian, siapkan penawaran dan kontrak kerja sesuai dengan jabatan dan jabatan. Siapkan surat pemberitahuan ucapan terima kasih kepada kandidat yang belum diterima. Ambil langkah ekstra ini untuk menjadikan citra perusahaan lebih baik di mata para pencari kerja.

Ketika orang yang terpilih dipanggil, yang perlu dilakukan adalah merundingkan gaji dan tunjangan perusahaan, seperti uang lembur, asuransi kesehatan, dll. Jangan lupa untuk memberitahu para kandidat tanggal mulai sehingga mereka memiliki cukup waktu untuk menyelesaikan tugas di perusahaan sebelumnya. Setiap perusahaan sangat membutuhkan karyawan yang berkualifikasi tinggi yang dapat melakukan pekerjaan terbaik sesuai dengan meja kerjanya. Selama ini kualitas pegawai tergantung dari tahapan atau prosedur perekrutan pegawai atau proses rekrutmen. Melalui proses rekrutmen karyawan yang baik, Anda akan mendapatkan karyawan berkualitas yang akan membantu mengembangkan perusahaan Anda.

a) Prosedur pencatatan waktu hadir 
Prosedur ini bertujuan untuk mencatat waktu hadir karyawan. Pencatatan waktu hadir diselenggarakan oleh fungsi pencatat waktu dengan manggunakan daftar hadir pada pintu masuk kantor administrasi atau pabrik. Pencatat waktu hadir dapat menggunakan daftar hadir biasa, yang karyawan harus menandatanganinya setiap hadir dan pulang dari perusahaan atau dapat menggunakan kartu hadir berupa clock card yang diisi secara otomatis dengan menggunakan mesin pencatatan waktu time recorder machine. Pencatatan waktu hadir ini diselenggarakan untuk menentukan gaji dan upah karyawan. Bagi karyawan yang digaji bulanan, daftar hadir digunakan untuk menentukan apakah karyawan dapat memperoleh gaji penuh, atau harus dipotong akibat ketidakhadiran mereka. Daftar hadir ini juga digunakan untuk menentukan apakah karyawan bekerja di perusahaan dalam jam biasa atau jam lembur, Sehingga dapat digunakan untuk menentukan apakah karyawan akan menerima gaji saja atau menerima tunjangan lembur yang terakhir ini umumnya bertarif di atas tarif gaji biasa .

b) Prosedur Pembuatan Daftar Gaji Dan Upah.

Fungsi pembuat daftar gaji dan upah membuat daftar gaji dan upah karyawan. Data yang dipakai adalah surat keputusan mengenai pengangkatan karyawan baru, pemberhentian karyawan, penurunan pangkat, daftar gaji bulan sebelumnya dan daftar hadir. Universitas Sumatera Utara c. Prosedur Distribusi Biaya Gaji dan Upah. Dalam prosedur distribusi biaya gaji dan upah, biaya tenaga kerja didistribusikan kepada departemen-departemen yang menikmati manfaat tenaga kerja. Distribusi biaya tenaga kerja ini dimaksudkan untuk pengendalian biaya dan perhitungan harga pokok produk.

c) Prosedur Pembayaran Gaji dan Upah.

Prosedur pembayaran gaji dan upah melibatkan fungsi akuntansi dan fungsi keuangan. Fungsi akuntansi membuat perintah pengeluaran kas kepada fungsi keuangan untuk menulis cek guna pembayaran gaji dan upah. Fungsi keuangan kemudian menguangkan cek tersebut ke bank dan memasukkan uang ke amplop gaji dan upah. Jika jumlah karyawan perusahaan banyak, pembagian amplop gaji dan upah biasanya dilakukan oleh juru bayar pay master . Pembayaran gaji dan upah dapat dilakukan dengan membagikan cek gaji dan upah kepada karyawan.

\section{Kebijakan perusahaan mengenai peraturan dan tata tertib pegawai}


1. Memuat Hak dan Kewajiban dari Pengusaha.

Tentu saja hal ini adalah mutlak dicantumkan. Pengusaha sebagai orang yang mempekerjakan berhak untuk menerima hasil pekerjaan secara maksimal sebagai hak pemberi kerja (pengusaha). Imbal baliknya sebagai pengusaha harus memberikan gaji yang layak atas pekerjaan yang dilakukan oleh karyawannya.

2. Hak dan Kewajiban dari Karyawan.

Pekerja yang dipekerjakan untuk menyelesaikan produk, berhak menerima upah saat pekerjaan selesai. Tentu saja hal ini diimbangi dengan kewajibannya dalam menyelesaikan pekerjaan sesuai standar yang telah ditetapkan perusahaan.

3. Syarat Bekerja

Berbicara mengenai perusahaan ada standarisasi sendiri untuk masuk didalamnya. Hal ini bertujuan untuk menjaga kualitas dari produk yang dihasilkan. Misalnya saja perusahaan hanya menerima lulusan dari teknik mesin untuk bekerja sebagai operator

4. Tata Tertib

Dalam peraturan perusahaan yang diterbitkan didalamnya mengandung tata tertib. Hal ini dimaksudkan agar terjadi keselarasan dan menghindari konflik antar karyawan.

5. Jangka waktu berlaku

Setiap peraturan yang dibuat memuat jangka waktu berlaku. Jangka waktu ini berisi penjelasan bahwa peraturan perusahaan hanya mengikat karyawan yang bekerja. Mereka yang telah resign atau pensiun sudah tidak terikat dengan peraturan tersebut lagi. Selain itu peraturan akan diberlakukan selama 2 tahun dan harus renewal kembali.

\section{Kebijakan penggajian dan pengupahan suatu perusahaan}

Dalam sistem penggajian karyawan, biasanya perusahaan memiliki sistem perhitungan sendiri dengan menggunakan excel ataupun software yang bisa didapatkan di berbagai situs online. Berikut ini akan dijelaskan secara umum sistem penggajian karyawan.

1. Bagian HRD menerima data kehadiran yang sudah valid untuk kemudian diproses dalam penggajian per orang.

2. Menghitung bagian pajak PPh 21 berdasarkan status jabatan maupun status keluarga.

3. Kemudian menerima rekapan revisi perhitungan pajak gaji dari bagian pajak, lalu membuat contoh slip gaji dan daftar gaji ke seluruh karyawan.

4. Di evaluasi oleh departemen atau divisi keuangan. 
5. Jika tidak ada evaluasi atau kesalahan, membuat cek tunai sebesar jumlah gaji seluruh karyawan lalu menyerahkannya kepada pimpinan perusahaan.

6. Cek tunai/bilyet kemudian ditransfer ke bank mitra untuk kemudian di transfer ke rekening masing-masing karyawan.

Semua proses ini dilakukan oleh bagian HRD sebuah perusahaan.

\section{Kebijakan mengenai kenaikan upah}

UU mengamanatkan setiap perusahaan untuk menyusun struktur dan skala upah sebagai pedoman kebijakan pengupahan, termasuk kenaikan upah berkala. Pasal 92 menegaskan:

1. Pengusaha menyusun struktur dan skala upah dengan memperhatikan golongan, jabatan, masa kerja, pendidikan, dan kompetensi.

2. Pengusaha melakukan peninjauan upah secara berkala dengan memperhatikan kemampuan perusahaan dan produktivitas.

3. Ketentuan mengenai struktur dan skala upah sebagaimana dimaksud dalam ayat (1) diatur dengan Keputusan Menteri.

Struktur dan skala upah adalah tingkat upah dari nominal terkecil sampai terbesar untuk setiap golongan jabatan dari yang terendah sampai yang tertinggi. Tujuannya adalah menciptakan sistem pengupahan yang berkeadilan, dengan mengurangi kesenjangan upah terendah dan tertinggi.

Struktur dan skala upah menggambarkan jenjang kenaikan upah standar berdasar golongan, jabatan, masa kerja, pendidikan, dan kompetensi masing-masing karyawan. Sesuai Peraturan Menteri Ketenagakerjaan (Permenaker) No 1 Tahun 2017 tentang Struktur dan Skala Upah, Pasal 4, penyusunan struktur dan skala upah dilakukan oleh pengusaha berdasarkan kemampuan perusahaan dan harus memperhatikan upah minimum yang berlaku.

\section{Kebijakan mengenai insentif}

Setiap perusahaan mempunyai cara masing-masing dalam memberikan insentif. Terdapat jenis jenis insentif adalah berikut ini.

1. Insentif Finansial

Insentif finansial yaitu jenis insentif yang diserahkan oleh perusahaan dalam bentuk uang baik digital maupun tunai. Uang insentif tersebut diberikan di luar gaji. Biasanya diterima karyawan bersamaan dengan penerimaan upah.

2. Insentif Non-Finansial 
Insentif non-finansial adalah jenis insentif dari perusahaan berupa hal lain selain uang. Biasanya bentuknya seperti fasilitas rumah, mobil, pelatihan, jaminan kesehatan, dana pensiun dan sejenisnya.

3. Insentif Sosial

Insentif sosial adalah bentuk insentif yang jarang disadari oleh karyawan. Contoh jenis insentif satu ini misalnya terjalinnya hubungan lebih baik dengan rekan kerja, pimpinan, hingga klien perusahaan.

\section{Kebijakan mengenai cuti dan sakit}

turan pemerintah mengenai cuti sakit terdapat dalam Pasal 93 UU Ketenagakerjaan Nomor 13 Tahun 2003, dalam pasal tersebut menjelaskan bahwa upah/gaji tidak akan dibayar apabila pekerja atau buruh tidak melakukan pekerjaannya.

Ketentuan tersebut tidak berlaku, dan pengusaha tetap wajib membayar upah/gaji pekerja/buruh, apabila :

- Pekerja/buruh sakit sehingga tidak dapat melakukan pekerjaannya

- Pekerja/buruh perempuan yang sakit pada hari pertama dan kedua saat haid sehingga tidak dapat melakukan pekerjaannya

Aturan di atas memperbolehkan karyawan yang sakit, termasuk perempuan yang mengalami sakit saat haid hari pertama dan kedua, untuk mengajukan cuti sakit karena tidak dapat melakukan pekerjaannya. Dalam keadaan seperti ini, perusahaan tetap wajib membayar upah/gajinya, meskipun karyawan yang bersangkutan tidak masuk kerja.

Ada beberapa hal yang perlu diperhatikan perusahaan terkait izin sakit karyawan, diantaranya adalah :

1. Memastikan apakah pekerja atau karyawan yang sakit sudah ikut serta dalam program asuransi atau belum.

2. Apabila karyawan yang bersangkutan belum terdaftar menjadi peserta BPJS Kesehatan, maka perusahaan harus memastikan siapa yang akan menanggung biaya pengobatan karyawan tersebut

3. Setiap perusahaan harus mempunyai kebijakan tersendiri terkait penggantian biaya pengobatan karyawan di luar tanggungan BPJS Kesehatan. Misalnya, perusahaan akan 
memberikan penggantian biaya pengobatan sebagian atau sepenuhnya untuk rawat inap, rawat jalan, rawat jalan lanjutan, pemeriksaan kehamilan, bea laboratorium, persalinan, dan pelayanan khusus lainnya. Ada juga perusahaan yang akan memberi penggantian biaya kacamata dan perawatan gigi.

4. Memastikan apakah pembayaran upah/gaji karyawan yang sakit sudah sesuai dengan Undang-Undang yang berlaku.

5. Mempunyai jaminan perlindungan bagi karyawan sakit dan yang mengalami kecelakaan kerja.

6. Jika karyawan mengalami kecelakaan kerja, maka seluruh biaya pengangkutan (meliputi biaya pemeriksaan, pengobatan, perawatan, biaya rehabilitasi, dll) akan ditanggung oleh BPJS. Dan bagi mereka yang sementara tidak mampu bekerja (mengalami cacat sebagian ataupun cacat total) akan mendapatkan santunan (berupa uang) yaitu santunan cacat sebagian, dan santunan cacat total.

\section{Pengaruh Cuti Sakit terhadap Upah/gaji bulanan}

Aturan mengenai berapa besarnya dana penggantian klaim cuti sakit karyawan yang tetap akan dibayar perusahaan diatur dalam Pasal 93 ayat (3), yaitu :

1. Jika karyawan sakit selama 4 bulan pertama akan dibayar $100 \%$ dari upah/gaji

2. Jika masih sakit dalam 4 bulan kedua akan dibayar $75 \%$ dari upah/gaji

3. Jika tetap sakit dalam 4 bulan ketiga dibayar 50\% dari upah/gaji

Dan jika masih tetap sakit dalam 4 bulan selanjutnya akan dibayar $25 \%$ dari upah/gaji, sebelum pemutusan hubungan kerja dilakukan oleh perusahaan. Biaya penggantian cuti sakit oleh perusahaan hanya dapat diberikan berdasarkan surat keterangan sakit dari dokter yang merawat karyawan yang bersangkutan. Atau bisa juga atas rekomendasi dokter apabila karyawan yang bersangkutan membutuhkan waktu istirahat yang lama.

\section{Kebijakan mengenai tunjangan}

Tunjangan Tetap adalah suatu pembayaran yang teratur berkaitan dengan pekerjaan yang diberikan secara tetap untuk pekerja dan keluarganya serta dibayarkan dalam satuan waktu yang sama dengan pembayaran upah pokok, seperti tunjangan istri, tunjangan anak, tunjangan perumahan, tunjangan kemahalan, tunjangan daerah dan lain-lain. 
Tunjangan makan dan tunjangan transportasi dapat dimasukkan dalam komponen tunjangan tetap apabila pemberian tunjangan tersebut tidak dikaitkan dengan kehadiran, dan diterima secara tetap oleh pekerja menurut satuan waktu, harian atau bulanan.

Tunjangan Tidak Tetap adalah suatu pembayaran secara langsung atau tidak langsung berkaitan dengan pekerja, yang diberikan secara tidak tetap untuk pekerja dan keluarganya serta dibayarkan menurut satuan waktu yang tidak sama dengan waktu pembayaran upah pokok, seperti tunjangan transportasi yang didasarkan pada kehadiran.

Tunjangan makan dapat dimasukkan ke dalam tunjangan tidak tetap apabila tunjangan tersebut diberikan atas dasar kehadiran. Pemberiannya bisa dalam bentuk uang atau fasilitas makan.

Evaluasi Unsur-Unsur Sistem Pengendalian Manajemen

\begin{tabular}{|l|l|l|}
\hline No & \multicolumn{1}{|c|}{$\begin{array}{c}\text { Unsur-Unsur Sistem Pengendalian } \\
\text { Manajemen }\end{array}$} & \multicolumn{1}{c}{ Hal-Hal Yang Mendukung } \\
\hline 1 & $\begin{array}{l}\text { Keahlian karyawan (pegawai) sesuai } \\
\text { dengan tanggung jawabnya. }\end{array}$ & $\begin{array}{l}\text { Sudah terdapat pemisahan tugas yang cukup } \\
\text { jelas dan dapat } \\
\text { dilihat dari struktur organisasi yang ada }\end{array}$ \\
\hline 2 & $\begin{array}{l}\text { Sistem pemberian wewenang, tujuan } \\
\text { dan teknik serta pengawasan yang } \\
\text { wajar untuk mengadakan } \\
\text { pengendalian atas harta, utang, } \\
\text { penerimaan, dan pengeluaran }\end{array}$ & $\begin{array}{l}\text { Hal ini dapat dilihat dari penjabaran tugas } \\
\text { manajer area } \\
\text { point ke tiga yaitu mengatur dan mengarahkan } \\
\text { kegiatan } \\
\text { pengendalian dan pengawasan, pelaksanaan, } \\
\text { dan } \\
\text { pemeliharaan jaringan. }\end{array}$ \\
\hline 3 & $\begin{array}{l}\text { Pengendalian terhadap penggunaan } \\
\text { harta dan dokumen serta formulir } \\
\text { yang penting. }\end{array}$ & $\begin{array}{l}\text { Hal ini dapat dilihat dari dokumen-dokumen } \\
\text { yang dibuat } \\
\text { dan dikeluarkan selalu diotorisasi } \\
\text { kebenarannya. Selain itu, } \\
\text { dokumen-dokumen disimpan dengan baik dan }\end{array}$ \\
\hline
\end{tabular}




\begin{tabular}{|l|l|l|}
\hline \multicolumn{1}{|l|}{} & & $\begin{array}{l}\text { rapi sehingga } \\
\text { memudahkan untuk mencari pada saat } \\
\text { diperlukan. }\end{array}$ \\
\hline 4 & $\begin{array}{l}\text { Periksa fisik harta dengan catatan } \\
\text { catatan harta dan utang, dan } \\
\text { mengadakan tindakan koreksi jika } \\
\text { dijumpai adanya perbedaan. }\end{array}$ & $\begin{array}{l}\text { Segala catatan-catatan yang ada selalu diperiksa } \\
\text { setiap } \\
\text { harinya, dan langsung dikoreksi saat itu juga } \\
\text { jika terjadi } \\
\text { kesalahan pada catatan tersebut. }\end{array}$ \\
\hline
\end{tabular}

\section{KESIMPULAN DAN SARAN}

\section{A. Kesimpulan}

Berdasarkan hasil penelitian, dapat diambil kesimpulan sebagai berikut :

B. Periksa fisik harta dengan catatan - catatan harta dan utang, serta mengadakan tindakan koreksi jika dijumpai adanya perbedaan. Selain itu segala bentuk catatan-catatan yang ada selalu diperiksa setiap harinya, dan langsung dikoreksi saat itu juga jika terjadi kesalahan pada catatan tersebut. Tujuannya agar tidak ada pencatatan dalam penulisan.

C. Pengendalian terhadap penggunaan harta dan dokumen serta formulir yang penting. Hal ini dapat dilihat dari dokumen-dokumen yang dibuat dan dikeluarkan selalu diotorisasi atau sudah diidentifikasi keabsahan dokumen tersebut dengan kebenaran, keseuainnya. Selain itu, dokumen-dokumen disimpan dengan baik dan rapi sehingga memudahkan untuk mencari pada saat diperlukan.

D. Pengendalian atas harta, utang, penerimaan, dan pengeluaran melalui sistem pemberian wewenang, tujuan dan teknik serta pengawasan yang wajar. Pembuktian tersebut dapat dilihat dari penjabaran tugas manajer yaitu mengatur dan mengarahkan kegiatan pengendalian dan pengawasan, pelaksanaan, dan pemeliharaan jaringan.

\section{E. Saran}


1) Ada baiknya jika perusahaan melakukan pelatihan secara berkesinambungan terhadap SDM yang mengolah data tentang gaji dan upah, agar data tentang gaji dan upah tersebut dapat diolah dengan baik, dan menghasilkan system informasi akuntansi penggajian dan pengupahan yang lebih efektif dan efisien.

2) Jaringan prosedur yang digunakan terkait system gaji sebaiknya lebih di efisienkan dalam penggunaannya, agar data yang dihasilkan lebih tepat dan dapat diproses dengan cepat, tanpa perlu dilakukannya pengiriman data ke jaringan prosedur lainnya yang akan menghabiskan banyak waktu.

3) Dalam sistem informasi akuntansi penggajian, sebaiknya perlu adanya pemisahan tugas dan wewenang yang jelas sehingga perangkapan fungsi dapat diminimalkan serta dapat meningkatkan pengendalian intern perusahaan. Dokumen yang digunakan dalam sistem akuntansi penggajian dan pengupahan karyawan hendaknya mendapat otorisasi dari bagian yang bertanggungjawab agar dapat mencegah adanya penyelewengan.

4) Untuk memudahkan manajemen melakukan pengawasan terhadap jalannya operasional perusahaan maka diperlukan bagian khusus yang menangani masalah pengendalian intern perusahaan, karena dalam bagian ini terdapat bagian khusus yang mengawasi bagian keuangan, personalia, serta operasional perusahaangian.

\section{DAFTAR PUSTAKA}

Eka Nurmala Sari, F. S. (2009). Pengaruh Sistem Pengendalian Manajemen Terhadap Kinerja Keuangan Peusahaan Pada Hotel Berbintang Di Kota Medan. Jurnal Riset Akuntansi Dan Bisnis, 9(2), 40. http://journal.umsu.ac.id/index.php/akuntan/article/download/458/420

Eko, S. (2018). Pentingnya Sistem Pengendalian Manajemen dalam Pengelolaan Usaha Kecil dan Menengah di Kabupaten Banyumas, Jawa Tengah. Kompartemen: Jurnal Ilmiah Akuntansi, 16(1), 64-83. 
Musa, S. H. (2013). Evaluasi Sistem Pengendalian Manajemen Untuk Meningkatkan Kinerja Manajer Penjualan Pada Pt. Hasjrat Abadi Manado. Jurnal Riset Ekonomi, Manajemen, Bisnis Dan Akuntansi, 1(4), 1790-1798.

Pabowo, R. G. M., \& Eldon, M. (2018). Kajian Pengetahuan Dalam Manajemen Bencana Di Kabupaten Tulungagung. Jurnal BENEFIT, 5(1), 60-77. http://www.jurnalunita.org/index.php/benefit/article/view/159

Sinain, S. G. (2013). Analisis Efektivitas Pengendalian Manajemen Penggajian Pt. Pln (Persero) Rayon Tomohon. Jurnal Riset Ekonomi, Manajemen, Bisnis Dan Akuntansi, 1(3), 1221-1230.

Yahya, F. A., B, S. A. E., \& Setyanto, I. (2021). Analisis Efektivitas Sistem Pengendalian Manajemen Penggajian pada PT . Aura Mandiri.

Yustien, R. (2012). Pengaruh Penerapan Sistem Pengendalian Manajemen Pada Pusat Pendapatan Dan Pusat Biaya Terhadap Kinerja Manajerial Rumah Sakit Umum Tipe B Di Provinsi Jawa Barat. Pekbis JuPengaruh Penerapan Sistem Pengendalian Manajemen Pada Pusat Pendapatan Dan Pusat Biaya Terhadap Kinerja Manajerial Rumah Sakit Umum Tipe B Di Provinsi Jawa Baratrnal, $4(1), 44-53$.

Anggraini, L. D. (2019). Pengaruh Sistem Pengendalian Manajemen Terhadap Kinerja Karyawan. Jurnal Akuntanika, 5(1), 1689-1699. (Anggraini, 2019) 